\title{
Antinutritional factors in the leaves of three forage trees: guamo, nacedero and matarratón
}

\author{
M. Rosales, T. R. Preston, W. F. Galindo, E. Murgueitio and J. Larrahondo \\ Convenio Interinstitucional para la Producción Pecuaria en el Valle del Rio Cauca (CIPAV), Apartado Aéreo 7482, \\ Cali, Colombia
}

\section{Introduction}

The experiment consisted in the phytochemical evaluation of three forage trees used for ruminants: guamo Inga spectabilis, nacedero Trichantera gigantea and matarratón Gliricidia sepium. The study also included a biological assay that was performed in the Cumbre (Valley), Colombia. The objective was to make a study of three different forage trees to establish a comparative table of their mineral composition and antinutritional components (phenols, alkaloids, saponins and steroids).

\section{Material and methods}

A biological assay was designed to determine the toxicity of the guamo leaf; with three Criolla goats of 2.5 years of age. One animal was assigned to each treatment. The measurements were taken at $0,0.5,1$, $1 \cdot 5,2,3$ and $4 \mathrm{~h}$, and the parameters measured were: pulse rate, respiration rate and rectal temperature.
The treatments were: $\mathrm{T} 1$ - guamo leaf offered ad libitum; T2 - forage of Pennisetum purpureum plus 21 of an extract of the volatile fraction of the guamo leaf with a concentration of 2000 p.p.m. of phenols; $T$ forage of Pennisetum purpureum offered ad libitum.

\section{Results}

The results of the chemical evaluation of the leaves are shown in Table 1.

As far as their nitrogen content is concerned, the three forages showed a good potential for their use in animal feeding. High levels of calcium, potassium and magnesium were observed in the leaves of nacedero.

The alkaloids and the saponins were low. They were therefore considered not to affect the health of the goats. The content of steroids present in the three trees were very low. The guamo $(0.3$ of tannins)

Table 1 Content of minerals, nitrogen and antinutritional factors in the foliage of three forage trees (g/kg material except where stated oth'ruvisi')

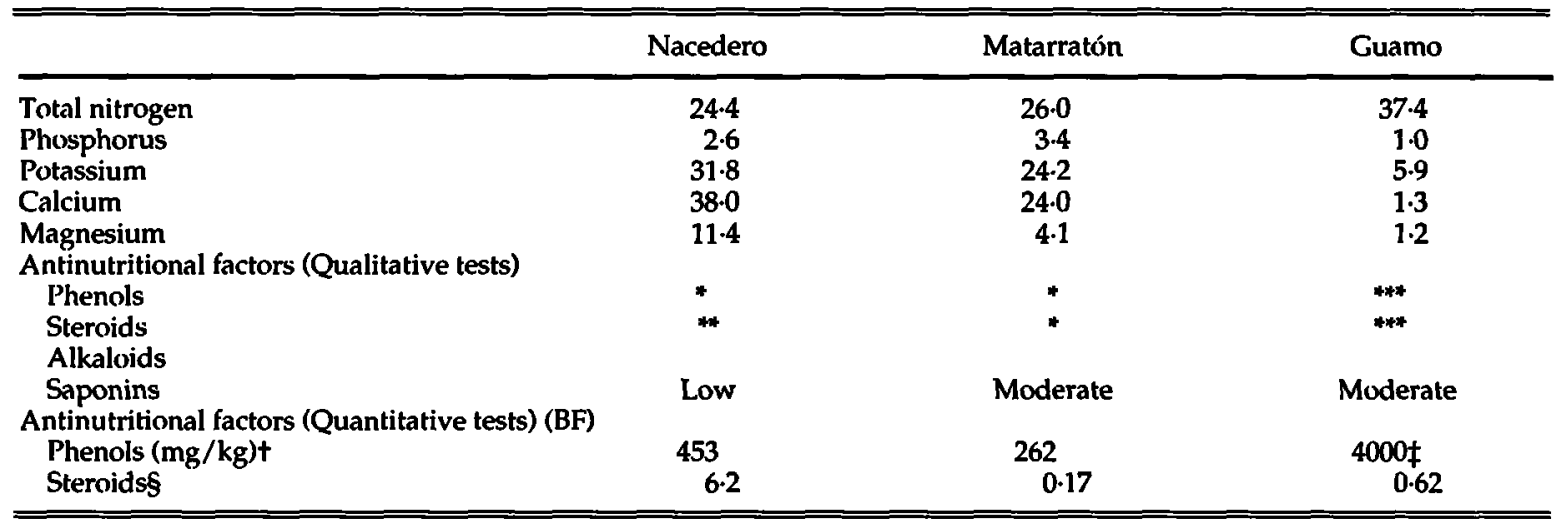

+ Expressed as caffeic acid.

$¥$ Results of TLC in phenols: chalconins, isoflavons and flavons.

$\S$ Expressed as cholesterol. 
reached the highest levels as far as their phenol content was concerned which significantly affected the degradability of the dry material (see Figure 1). The leaves of matarratón and nacedero present a high level of degradability. In the case of guamo leaf, the degradability of the dry material is too low, which indicates that the ruminant bacteria cannot degrade it. It is possible that the quantity of protein that is offered is not fully utilized by the animal. The flavonins associated with tannins and polyphenols inhibit the digestion and forms insoluble complexes with the protein.

During the biological assay the rectal temperature remained constant for the three goats. The pulse rate of $\mathrm{T} 1$ decreased notably, resulting in a difference of 40 pulsations per min with respect to the control, the pulse rate of $\mathrm{T} 2$ followed the tendency of the control although it showed an increase in the 1st $h$, due to the rapid ingestion of the phenols in the liquid solution. (see Figure 2). The respiration rate in $\mathrm{T} 1$ showed an increase starting from the $3 \mathrm{rd} h$, as a consequence of the low pulse rate and to improve oxygenation. In the other treatments differences were not found. The results in $\mathrm{T} 1$ were most likely due to intoxication by flavons or isoflavons, present in the leaves of guamo.

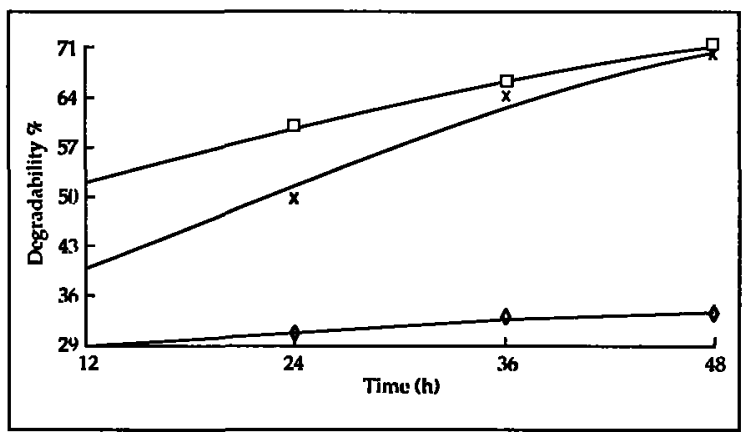

Figure 1 Dry matter degradability of three foliage trees in relation to their total phenol content (given in brackets): $U$ = nacedero $(453 \mathrm{mg} / \mathrm{kg}) ; x=$ matarratón $(262 \mathrm{mg} / \mathrm{kg})$; $\vartheta=$ guamo $(4000 \mathrm{mg} / \mathrm{kg})$.

\section{Conclusions}

Taking into consideration all the chemical analyses made, the leaf of matarratón is the best forage for tropical diets. It shows the highest nutritional components, a good level of degradability and the lowest toxins compared with the other forages studied.

The leaf of nacedero contains the highest levels of calcium and phosphorus, which makes it ideal for lactating animals. Furthermore due to its chemical components it can be considered as a forage suitable for tropical diets in areas where matarratón is not produced.

The leaf of guamo, in contrast to all the other forages, has low mineral content (of nutritional value) and high quantities of antinutritional substances, especially phenols which can produce toxicity which manifested itself as changes in the respiration and pulse rates.

\section{Acknowledgements}

M. Rosales acknowledges IFS grant no. B/1441-1 and E. Murgueitio acknowledges IFS grant no. B/1214-1.

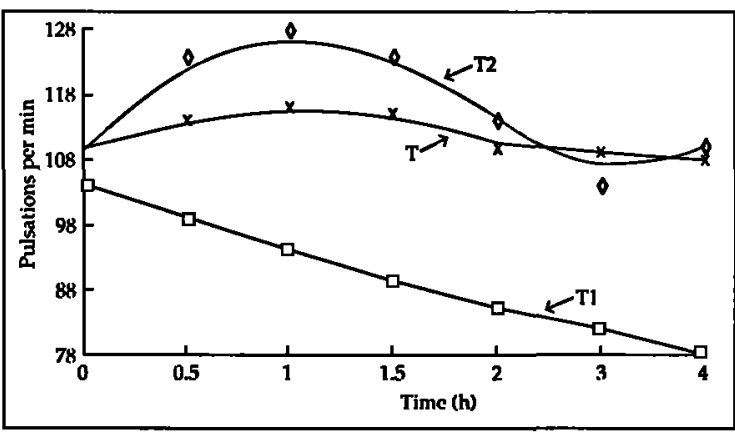

Figure 2 Variation in pulse rate of goats of three biological treatments: $x=$ control; $\square=$ guamo leaves; $0=$ leaf extract. 